\title{
Effect of Task Experience on Iranian EFL Learners' Level of Anxiety and Performance on Task-based Tests
}

\author{
Khalil Motallebzadeh (Corresponding author) \\ Department of English, Torbat-e-Heydareih Branch, Islamic Azad University (IAU), Torbat-e-Heydareih, Iran \\ Email: k.motalleb@iautorbat.ac.ir; kmotallebz@gmail.com \\ Sepideh Mirzaee \\ Department of English, Mashhad Branch, Islamic Azad University (IAU), Mashhad, Iran \\ Email: spdmirzaee@gmail.com \\ Purya Baghaei \\ Department of English, Mashhad Branch, Islamic Azad University (IAU), Mashhad, Iran \\ Email: pbaghaei@mshdiau.ac.ir; puryabaghaei@gmail.com
}

\begin{abstract}
Anxiety, which changes into stress and nervous tension while taking a test, is usually considered as a destructive factor for test-takers. Many EFL/ESL teachers and testing scholars have tried to reduce this debilitative anxiety (Tóth, 2007). Recently, there has been an increased motivation toward development of performance-based tests in most language teaching programs, focusing on test-takers' actual proficiency rather than their abstract knowledge of $\mathrm{L} 2$ rules. This new trend has led to a new challenge: test-takers' unfamiliarity with performance-based tasks and as a result, increased test-taking anxiety. The present study is an attempt to examine the effect of learners' experience of language tasks on the level of their anxiety in performance-based or task-based tests. In addition, this research tried to find the relationship between learners' anxiety and the quality of their performances in such tests. To conduct this study, 300 Iranian EFL students studying at the Islamic Azad University, Iran, were randomly selected. The participants were asked to sit for a pretest, as a homogenizing instrument. 100 participants, meeting the requirements of the test, were randomly divided into 2 experimental and 2 control groups. The participants also completed Horwitz Second Language Anxiety Questionnaire (HSLAQ, 1991). Tasks coaching and practice were given to the participants in experimental group as treatment. Subsequently, participants' performances in both groups were compared on the results of a performance-based test. Furthermore, in order to measure the learners' increased or decreased level of anxiety, the participants were asked to take HSLAQ after treatment. The results revealed that task experience can significantly reduce participants' anxiety level in task/performance-based tests.
\end{abstract}

Index Terms - task-based test, performance-based test, task experience, test anxiety, second language anxiety

\section{INTRODUCTION}

The past twenty years have seen a real increase in the number of studies dealing with anxiety in the L2 domain, which is attributable to the significant advances in the theory and measurement of L2-related anxiety since the mid1980s (MacIntyre \& Gardner, 1991; Young, 1991, 1994; MacIntyre, 1999; Horwitz, 2001). The role played by anxiety in foreign or second language learning is an issue which has long been in the center of attention of language investigators. As early as in the 1970s, a period noticeable by an increase of research focusing on the learner, anxiety, among other individual learner differences anticipated to affect language learning success, started to be examined as a potential factor influencing L2 achievement (Dörnyei, 2005; Horwitz, 1990).

This study deals with the examination of the debilitative anxiety and its effect on test performance of EFL/ESL learners. Since performance-based assessments are of crucial values today, and consequently learners' proficiency is more important than their abstract knowledge of language rules, it seems that learners' unfamiliarity with tasks increases their level of anxiety in language performance tests. Therefore this study examines the learners' task experience before test and its effect on their performances in performance- based assessments and also increasing or decreasing their level of anxiety and their effects in these kinds of tests.

\section{REVIEW OF THE LITERATURE}

In the literature, not just the relationship between anxiety and language learning is searched but also the relationship between test anxiety and academic performance was done in some researches. Test anxiety is a multidimensional construct that has been defined as "the set of phenomenological, psychological and behavioral responses that 
accompany concern about possible negative consequences or failure on an exam or similar evaluative situation" (Zeidner, 1998, p. 17).

According to one study done by Tóth (2007) two basic approaches have been considered to the study of anxiety in the L2 domain. These are labeled (1) the anxiety transfer, and (2) the unique anxiety approach, which are reflective of different conceptualizations of L2-related anxiety (Horwitz \& Young, 1991; MacIntyre, 1999). As McCroskey (1977) maintains, language anxiety integrates three related performance anxiety: 1) communication apprehension 2) test anxiety, and 3) fear of negative evaluation. Because of its emphasis on mutual interaction, the construct of communication fear is quite relevant to the conceptualization of foreign language anxiety.

Meanwhile, test anxiety refers to a type of performance anxiety stemming from a fear of failure (Gordon and Sarason 1955, Sarason 1980). It is the tendency to become alarmed about the consequence of inadequate performance on a test or other evaluation (Sarason, 1984, cited in Oxford, 1999, p. 64). Test anxious students often put unrealistic demands on themselves and feel that anything less than a perfect test performance is a failure.

\section{A. Effects of Foreign Language Learning Anxiety}

Foreign language learning anxiety has been related to many negative outcomes that can be categorized as physical, psychological, or social (e.g., Bailey, Daley, and Onwuegbuzie, 1999; Oxford 1999). Physical symptoms consist of speedy heartbeat, muscle tension, dry mouth, and extreme perspiration. Psychological symptoms consist of embarrassment, feelings of defenselessness, fear, going blank, and poor memory remembrance and retention among others. Negative social behavior may be illustrated in such ways as unsuitable silence, reluctance to take part, nonattendance, and withdrawal from the course. These effects can lead to poor performance and low success. Researches (e.g., Young, 1999) suggest that for many learners, success and insistence in foreign language learning considerably depends both on the teacher's ability to reduce the devastating effects of classroom anxiety and the learners' ability to handle the anxiety that cannot be hindered or avoided.

In contradiction of this debilitative anxiety, there is an indication that a certain degree of anxiety may be useful to learners (Scovel, 1978). This kind of anxiety is usually referred to as facilitative anxiety, it motivates learners to study harder and make stronger efforts to achieve better in classroom. There are some disagreements, however, as to whether this emotional state is really anxiety, or the terms such as attention and alertness may be more precise.

Recently Andrade and Williams (2009) tried to determine the relationship between anxiety and pair and small group work by using a questionnaire. They aimed to see whether the anxiety level of students can be reduced by using pair or small group tasks in their conversational activities in the classroom or not. Pair and small group work are believed to contribute to a low-anxiety classroom situation (e.g., Koch and Terrell, 1991; Price, 1999; Young, 1999). So the Results of their study illustrated that there were significant differences for almost all groups of students, excluding gender factor, actively participating more in pairs or small groups than in a whole class situation.

\section{B. Foreign Language Anxiety and Assessment}

Maehr and Midgley (1991) and Pintrich and Schrauben (1992) discovered the impact of test anxiety on students' performance often influenced by the evaluation practices of the classroom teacher. In stressful conditions, as opposed to game-like conditions, high test-anxious children functioned poorly when expected to achieve, but low-anxious children performed well in this environment (Hembree, 1988). In developing a measurement for gauging the level of test anxiety, Sarason (1975) devised the Test Anxiety Scale. This measure is used to determine a level of test anxiety among collegeage students. It is typically administered to large groups of college students. Sarason determined that individuals with high test anxiety exhibited the following cognitions when facing an evaluative task: a) the situation is seen as difficult, challenging, and threatening; b) the individual sees himself or herself as ineffective in handling, or inadequate to, the task at hand; c) the individual focuses on undesirable consequences of personal inadequacy; d) self-deprecatory preoccupations are strong and interfere or compete with task-relevant cognitive activity; e) the individual expects and anticipates failure and loss of regard by others.

To achieve the goals of the present quasi-experimental study, the following research questions were posed:

Q1. Does task experience have any significant effect on EFL learners' performance in task-based tests?

Q2. Does task experience have any significant effect on decreasing the EFL learners' level of anxiety in task-based tests?

Q3. Does task experience have any significant effect on increasing the EFL learners' level of anxiety in task-based tests?

Q4. Does decreasing the EFL learners' level of anxiety have any significant effect on their performance in taskbased tests?

Q5. Does increasing the EFL learners' level of anxiety have any significant effect on their performance in task-based tests?

To come up with reasonable results on the basis of the aforementioned research question, the following null hypotheses were proposed:

HO1. Task experience has no significant effect on EFL learners' performance in task-based tests.

HO2. Task experience has no significant effect on decreasing the EFL learners' level of anxiety in task-based tests.

HO3. Task experience has no significant effect on increasing the EFL learners' level of anxiety in task-based tests. 
HO4. Decreasing the EFL learners' level of anxiety has no significant effect on their performance in task-based tests. HO5. Increasing the EFL learners' level of anxiety has no significant effect on their performance in task-based tests.

\section{METHOD}

\section{A. Participants}

The participants in this study were intermediate adult EFL Iranian students taking reading comprehension courses in Islamic Azad University, Torbat-e-Heydareih and Mashhad branches, Iran. The male and female participants $(\mathrm{N}=127$, 17 males and 110 females), aged 18 to 30 , attend 4 separated classes taught by 4 different teachers. Two classes $(\mathrm{N}=63$, 9 males and 54 females) were chosen as the control group and two other classes ( $\mathrm{N}=64,8$ males and 56 females) as the experimental group.

\section{B. Instrumentation}

To collect the required data, several instruments were employed in this study:

1. Nelson Test. In order to make sure that all participants were homogeneous and truly at the same level of language proficiency, the Nelson Test (ver. 100A) developed by Fowler, W.S. \& Coe, N. (1976) was administered to a group of 147 students. The test contained 50 items. 130 students were found suitable for this study. The reliability index of this test was estimated through Cronbach's Alpha as .82.

2. Horwitz Second Language Anxiety Questionnaire (HSLAQ). This instrument was developed by Horwitz (1991) to determine the learners' level of anxiety in classrooms and during test administrations. This inventory included 50 items in likert scale. The reliability of this anxiety questionnaire was reported as .87 in Cronbach's Alpha.

3. Researchers-made Test Battery. This instrument included 20 task-based items which was employed to assess the participants' level of achievement during the course. The instrument covered those tasks practiced throughout the course. To determine the effect of the treatment, the instrument was used as the study pretest and post-test.

\section{Procedure}

The treatment lasted 15 weeks, 2 sessions per week, excluding the sessions assigned for the tests. Among the four groups $(\mathrm{N}=127)$, two were selected as control $(\mathrm{N}=63)$ and the other two groups as experimental $(\mathrm{N}=64)$, randomly. To ensure the homogeneity of the groups at the outset of the study, 147 participants took Nelson Test (ver. 100A). Analyzing the results for the test, the researchers could select 127 participants (17 males and 110 females) as the study subjects. The participants also took a pretest including reading comprehension items to ensure their level of reading ability in English.

To determine the participants' level of anxiety, the Horwitz Second Language Anxiety Questionnaire was employed. All participants completed the items in a five-response scale, ranging from strongly agree to strongly disagree. This selection regarded similarity in readability and themes. In each session, the researchers presented several reading tasks to the participants in experimental groups. The learners were asked to practice individually and in groups. The tasks included several challenging activities such as exploration, discovery, and guessing. The participants in control groups attended conventional classes and took reading passages with no tasks. These participants were asked to read the passages, look for words in their dictionaries and answer reading comprehension questions following the texts. At the end of the course, all participants took the study post-test as well as the Horwitz anxiety inventory.

\section{RESULTS AND DISCUSSIONS}

Having collected the required data based on the mentioned data collection instruments and procedures, the researchers conducted data analysis and tested the hypotheses formulated for the present study.

Results for Test of Homogeneity

To check the homogeneity of the total participants $(\mathrm{N}=230)$, the Nelson Test, version $(100 \mathrm{~A})$ was administered. Table 1 illustrates the descriptive statistics of participants' scores.

TABLE 1:

RESULTS OF DESCRIPTIVE STATISTICS FOR NELSON AS HOMOGENIZING TEST

\begin{tabular}{lllll}
\hline \multirow{2}{*}{ Test } & \multirow{2}{*}{ Mean } & SD & $\mathrm{N}$ & Malid \\
\cline { 4 - 5 } & & 8.63 & 103 & 127 \\
\hline Nelson & 32.40 & 8.63 & 103 & \\
\hline
\end{tabular}

As the results of Table 1 show, mean is 32.40 and the standard deviation is 8.63 . Here, only participants $(\mathrm{N}=127)$ whose scores fall within one standard deviation below and above the mean, i.e. between 16.55 and 28.89 were found valid to be included as the subjects of this study in control and experimental groups. The other participants $(\mathrm{N}=20)$ were found missing and were excluded from the study. Meanwhile, to ensure true homogeneity of the participants $(\mathrm{N}=127)$ in control ( $\mathrm{N}=63$ ) and experimental ( $\mathrm{N}=64)$ groups, an independent-sample t-test was conducted, (see Table 2). 
TABLE 2:

RESULTS OF T-TEST ANALYSIS FOR NELSON AS HOMOGENIZING TEST

\begin{tabular}{lllllll}
\hline Groups & $\mathrm{N}$ & $\mathrm{M}$ & $\mathrm{SD}$ & $\mathrm{t}$ & $\mathrm{df}$ & $\mathrm{p}$ \\
\hline Cont. & 63 & 31.30 & 1.72 & 1.56 & 38 & .12 \\
Exp. & 64 & 30.91 & 1.54 & & & \\
\hline
\end{tabular}

As the results of Table 2 show, there is no statistically significant difference $[\mathrm{t}(38)=1.56, \mathrm{p}=.12$ (two-tailed)] between control $(\mathrm{M}=31.30, \mathrm{SD}=1.72)$ and experimental $(\mathrm{M}=30.91, \mathrm{SD}=1.54)$ groups with regard to language proficiency which confirms the homogeneity of the participants at the outset of the study.

Having collected the results of Horwitz Second Language Anxiety Questionnaire (HSLAQ) in the pretest, the researchers analyzed the data for total test anxiety employing independent t-test. The purpose of this analysis was to estimate the participants' level of anxiety before the study began. Table 3 shows the results for this analysis.

TABLE 3:

RESULTS OF T-TEST ANALYSIS FOR TOTAL TEST ANXIETY (PRETEST)

\begin{tabular}{lllllll}
\hline Groups & $\mathrm{N}$ & $\mathrm{M}$ & $\mathrm{SD}$ & $\mathrm{t}$ & $\mathrm{df}$ & $p$ \\
\hline Exp. & 64 & 23.21 & 8.13 & .546 & 125 & .586 \\
Cont. & 63 & 22.42 & 8.18 & & & \\
\hline
\end{tabular}

As the results of Table 3 show, there is no statistically significant difference $[\mathrm{t}(125)=.546, \mathrm{p}=.586]$ between experimental $(M=23.21, S D=8.13)$ and control $(M=22.42, S D=8.18)$ groups with regard to general anxiety level which confirms the homogeneity of the participants at the outset of the study.

To investigate the effect of study treatment, the participants' reading comprehension ability was assessed in posttests via t-test analysis. Table 4 shows the results for this analysis.

TABLE 4:

RESULTS OF T-TEST ANALYSIS FOR TASK-BASED READING COMPREHENSION (POSTTEST)

\begin{tabular}{llllll}
\hline Groups & $\mathrm{N}$ & $\mathrm{M}$ & $\mathrm{SD}$ & $\mathrm{t}$ & $\mathrm{df}$ \\
\hline Exp. & 64 & 15.48 & 3.27 & 5.99 & 125 \\
Cont. & 63 & 12.09 & 3.09 & & \\
\end{tabular}

As the results of Table 4 show, there is a statistically significant difference [ $\mathrm{t}(125)=5.99, \mathrm{p}=.00]$ between experimental $(\mathrm{M}=15.48, \mathrm{SD}=3.27)$ and control $(\mathrm{M}=12.09, \mathrm{SD}=3.09)$ groups with task-based reading comprehension ability. This difference indicates that the participants in experimental group outperformed those in control group revealing the effect of task experience on test performance. Therefore, the first null hypothesis that task experience has no significant effect on EFL learners' performance in task-based tests is rejected.

To measure the effect of task experience on the participants' anxiety level, the researchers analyzed the data for total and individual subcategories of the HSLAQ, employing independent t-test. Tables 5 and 6 show the results for these analyses.

TABLE 5:

RESULTS OF T-TEST ANALYSIS FOR TOTAL TEST ANXIETY (PRETEST)

\begin{tabular}{lllllll}
\hline Groups & $\mathrm{N}$ & $\mathrm{M}$ & $\mathrm{SD}$ & $\mathrm{t}$ & $\mathrm{df}$ & \\
\hline Exp. & 64 & 22.25 & 6.94 & .780 & 125 & .437 \\
Cont. & 63 & 21.28 & 6.98 & & \\
\hline
\end{tabular}

According to the results of Table 5, participants in experimental group $(\mathrm{M}=22.25, \mathrm{SD}=6.94)$ were slightly better in their total anxiety compared to those in control group $(\mathrm{M}=21.28, \mathrm{SD}=6.98)$ although the results do not reveal a significant difference [ $\mathrm{t}(49)=.780, \mathrm{p}=.437]$. This may indicate that the participants in both groups have had enough experience throughout the course to control their level of anxiety. Therefore, the second null hypothesis that task experience has no significant effect on decreasing the EFL learners' level of anxiety in task-based tests is rejected. Meanwhile, the third null hypothesis that task experience has no significant effect on increasing the EFL learners' level of anxiety in task-based tests is accepted.

Comparing results of tables 4 and 5, it is clear that the participants in experimental groups had lower levels of total anxiety as well as higher performances on task-based tests. These findings reject the fourth and fifth null hypotheses that decreasing or increasing EFL learners' level of anxiety has no significant effect on their performance in task-based tests.

To analyze weather the two groups performed exactly the same on various subcategories of the HSLAQ, a t-test analysis was conducted for each subcategory. Table 6 shows the results. 
TABLE 6:

RESULTS OF T-TEST ANALYSIS FOR HSLAQ SUBCATEGORIES (POSTTEST)

\begin{tabular}{llllllll}
\hline Subcategory & Groups & $\mathrm{N}$ & $\mathrm{M}$ & $\mathrm{SD}$ & $\mathrm{t}$ & $\mathrm{df}$ & $p$ \\
\hline \multirow{2}{*}{ Others' views } & Exp. & 64 & 2.71 & 1.60 & .212 & 125 & .312 \\
& Cont. & 63 & 3.03 & 1.85 & & & \\
\hline \multirow{2}{*}{ Own self-image } & Exp. & 64 & 2.38 & 1.38 & .038 & 125 & .047 \\
& Cont. & 63 & 3.23 & 1.68 & & & \\
\hline \multirow{2}{*}{ Future security } & Exp. & 64 & 3.15 & 1.12 & .829 & 125 & .000 \\
& Cont. & 63 & 3.07 & 1.14 & & & \\
\hline \multirow{2}{*}{ Lack of preparation } & Exp. & 64 & 2.84 & 1.71 & .180 & 125 & .704 \\
& Cont. & 63 & 2.95 & 1.59 & & & \\
\hline \multirow{2}{*}{ Bodily reactions } & Exp. & 64 & 2.25 & 1.54 & .266 & 125 & .264 \\
& Cont. & 63 & 2.58 & 1.83 & & & \\
\hline \multirow{2}{*}{ Thought disruptions } & Exp. & 64 & 4.65 & 1.97 & .070 & 125 & .026 \\
& Cont. & 63 & 5.07 & 2.33 & & & \\
\hline \multirow{2}{*}{ General test-taking anxiety } & Exp. & 64 & 2.71 & 1.31 & .144 & 125 & .565 \\
& Cont. & 63 & 2.85 & 1.51 & & & \\
\hline
\end{tabular}

As the results of Table 6 show, except for own self-image $(\mathrm{M}=2.38, \mathrm{SD}=1.38)$ [t $(125)=.038, \mathrm{p}=.047]$, future security $(\mathrm{M}=3.15, \mathrm{SD}=1.12)[\mathrm{t}(125)=4.24, \mathrm{p}=.000]$, and thought disruption $(\mathrm{M}=4.65, \mathrm{SD}=1.97)[\mathrm{t}(125)=1.11$, $\mathrm{p}=.026]$, there is no statistically significant difference between experimental and control groups with regard to anxiety subcategories. This indicates that the task experience employed in experimental group can impact participants' level of anxiety control particularly understanding their own image, their security for the future and monitoring thought disruption.

\section{CONCLUSIONS}

As the findings of this study demonstrate, task experience, acquired from task-based activities, can decrease learners' anxiety level during a task-based test particularly in novel conditions. The results also proved that task experience has significant effect on EFL learners' test performance. It showed that learners' reading ability in a second or foreign language depends on their prior experience on a particular classroom task. Meanwhile, the results of the present study indicated that task experience can significant decrease the EFL learners' level of anxiety in task-based tests. This also maintains that task experience can affect participants' level of anxiety particularly understanding their own image, their security for the future and monitoring thought disruption.

In addition, the results indicated that to achieve a better performance in a task-based or performance-based test, task experience seems an indispensible prerequisite. Also it can be stated that many variables may interact to affect language learning, but foreign language anxiety should be of considerable concern to language educators and students because of its potential impact, not only on proficiency, but also on students' affective reactions, hence their attitude toward language learning in general.

Besides, the findings of this study may have some hints for English teachers and educators. Due to popularity of performance-based tests as a tests of language proficiency, EFL teachers can be encouraged to employ various tasks in their sill-based courses such reading or listening comprehension. This may bring an opportunity for test familiarity and in return decreases test anxiety. Therefore, it seems that understanding the effects of language anxiety can help both teachers and learners in the way that teachers can control its effect by improving their teaching and students by using appropriate strategies provided by teachers.

\section{ACKNOWLEDGEMENTS}

The researchers would like to thank Islamic Azad University (IAU), Torbat-e-Heydareih branch, Iran for funding this study. This is a part of a research project entitled 'The Effect of Task Experience on EFL Learners' Level of Anxiety and Performance on Task-based Tests'. Also, they would like to acknowledge the anonymous teachers and participants who helped them with conducting this research and collecting the required data.

\section{REFERENCES}

[1] Andrade and Williams. (2009). Foreign Language Learning Anxiety in Japanese EFL University Classes: Physical, Emotional, Expressive, and Verbal Reactions. Sophia Junior College Faculty Journal, 29, 1-24.

[2] Dörnyei, Z. (2005). The psychology of the language learner: Individual differences in second language acquisition. Mahwah, NJ: Lawrence Erlbaum Associates.

[3] Gordon E.M. and Sarason S.B. (1955). The relationship between "test anxiety" and "other anxieties". J Pers. 23(3): 317-23.

[4] Hembree, R. (1988). Correlates, causes, and treatment of test anxiety. Review of Educational Research, 58, 47-77.

[5] Horwitz, E. K. (1990). Attending to the affective domain in the foreign language classroom. In: S. S. Magnan (Ed.), Shifting the instructional focus to the learner (pp. 15-33). Middlebury, VT: Northeast Conference on the Teaching of Foreign Languages.

[6] Horwitz, E. K., \& Young, D. J. (Eds.). (1991). Language anxiety: From theory and research to classroom implications. Englewood Cliffs, NJ: Prentice-Hall.

[7] Horwitz, E. K. (2001). Language anxiety and achievement. Annual Review of Applied Linguistics, 21, 112-126. 
[8] Koch, A., S. and T., D. Terrel. 1991. 'Affective reactions of foreign language students to natural approach activities and teaching techniques'; in Horwitz E., K. and D. J. Young (eds.). pp. 109-126.

[9] MacIntyre, P. D. (1999). Language anxiety: A review of the research for language teachers. In D. J. Young (Ed.), Affect in foreign language and second language learning: A practical guide to creating a low-anxiety classroom atmosphere (pp. 24-45). Boston: McGraw-Hill.

[10] MacIntyre, P. D., \& Gardner, R. C. (1991). Methods and results in the study of anxiety and language learning: A review of the literature. Language Learning, 41, 85-117.

[11] Maehr, M.L. and Midgley, C. (1991). "Enhancing Student Motivation: A Schoolwide Approach," Educational Psychologist 26, pp. 399-427.

[12] McCroskey, J.C. (1977) "Oral Communication Apprehension: A Summary of Recent Theory and Research". Human Communication Research 4: 78-96.

[13] Oxford, R. (1999a). Anxiety and the language learner: New insights (pp. 58-67). In Jane Arnold (Ed.), Affect in language learning. Cambridge, UK: Cambridge University Press.

[14] Pintrich, P.R. and Schrauben, B. (1992). "Students' Motivational Beliefs and Their Cognitive Engagement in Classroom Academic Tasks," in D. Shuck and J. Meece (eds.), Student Perceptions in the Classroom: Causes and Consequences. Erlbaum. pp. 149-183.

[15] Price, M. L. (1999). The subjective reactions of foreign language students to Natural approach activities and teaching techniques. In E. K. Horwitz \& D. J. Young (Eds.). Language anxiety: From theory and research to classroom Implications (pp. 101-126). Englewood Cliffs, NJ: Prentice Hall. 86

[16] Sarason, I. G., (1975). Test anxiety, attention and the general problem of anxiety. In C. D. Spielberger \& I. G. Sarason (Eds.), Stress and anxiety. Vol. 1, Washington, DC: Hemisphere.

[17] Sarason, I. G. (1980). Test anxiety: Theory, research, and applications. Hillsdale, 87NJ: Lawrence Erlbaum Associates.

[18] Sarason, I. G. (1984), Stress, anxiety, and cognitive interference: Reactions to Tests. Journal of Personality and Social Psychology, 46, 929-938.

[19] Scovel, T. (1978). The effect of affect: A review of the anxiety literature. Language Learning, 28, 129-142.

[20] Young, D. J. (1991). Creating a low-anxiety classroom environment: What does language anxiety research suggest? The Modern Language Journal, 75, 426-439.

[21] Young, D. J. (1994). New directions in language anxiety research. In: C. A. Klee (Ed.), Faces in a crowd: The individual learner in multisection courses (pp. 3-45). Boston: Heinle \& Heinle Publishers.

[22] Young, D. J. (1999). Affect in foreign language and second language learning. Boston, MA: McGraw-Hill.

Khalil Motallebzadeh is assistant professor at the Islamic Azad University (IAU) of Torbat-e-Heydareih and Mashhad Branches, Iran. He is a widely published established researcher in language testing and e-learning. He has been a visiting scholar at the University of Illinois at Urbana Champaign (UIUC) in 2007-2008. He is also an accredited teacher trainer of the British Council since 2008 and is currently the Iran representative of Asia TEFL.

Sepideh Mirzaee holds MA in TEFL and is an instructor at the Islamic Azad University (IAU), Mashhad branch, Iran. She has presented in various international conferences and published several articles in academic journals. Her areas of interests are teaching methodology, discourse analysis and language assessment.

Purya Baghaei is assistant professor at the Islamic Azad University (IAU) of Mashhad Branch, Iran. He is a widely published established researcher in language testing and application of Rasch Modeling in educational and social science research. 